\title{
Soil fertility status and nutrient recommendations based on soil analysis of Jaisalmer district of western Rajasthan
}

DINESH KUMAR, S. R. YADAV, RAMANDEEP KAUR, ANIRUDH CHOUDHARY AND BRIJ SINGH MEENA

Received : 20.01.2017; Revised : 23.04.2017; Accepted : 04.05.2017

MEMBERS OF RESEARCH FORUM:

Corresponding author: DINESH KUMAR, Department of Soil Science, College of Agriculture, S.K. Rajasthan Agricultural University, BIKANER (RAJSTHAN) INDIA

Email:dkrachiata@gmail.com

Co-authors :

S.R. YADAV, RAMANDEEP

KAUR, ANIRUDH

CHOUDHARY AND BRIJ SINGH

MEENA, Department of Soil

Science, College of Agriculture, S.K.

Rajasthan Agricultural University, BIKANER (RAJSTHAN) INDIA

\section{Summary}

The present investigation was carried out for assessment of soil fertility status of Jaisalmer district of western Rajasthan. For this purpose 125 representative soil samples were collected from two Panchayat Samiti i.e. Sankda village Ujala and Jaisalmer village Basanpeer and Amersagar of Jaisalmer district. These soil samples were analyzed for soil properties, macro and micronutrient fertility status. The soils were moderately alkaline to very strongly alkaline in reaction with an average $\mathrm{pH}$ of 9.75 . The $\mathrm{EC}$ value varied from 0.05 to $0.71 \mathrm{dS} / \mathrm{m}$ with average value of $\mathrm{EC}$ is $0.25 \mathrm{dS} / \mathrm{m}$. The organic carbon content ranged from 0.01 to 0.70 per cent with an average value of 0.09 per cent. Available nitrogen, phosphorus $\left(\mathrm{P}_{2} \mathrm{O}_{5}\right)$, potassium $\left(\mathrm{K}_{2} \mathrm{O}\right)$ and sulphur (ppm) content of the soils ranged from 13.53 to $230.07,5.43$ to $56.72,170.13$ to $379.95 \mathrm{~kg} \mathrm{ha}^{-1}$ and 0.88 to $21.76 \mathrm{ppm}$ with an average value of $131.95,25.96,258.13 \mathrm{~kg} \mathrm{ha}^{-1}$ and 11.34 ppm, respectively. However, available micronutrient DTPA $\mathrm{Zn}, \mathrm{Fe}, \mathrm{Cu}$ and $\mathrm{Mn}$ ranges varied from $0.04-1.63,1.05-3.94,0.01-0.21$ and $0.14-2.88 \mathrm{ppm}$ with an average value of $0.51,0.21,0.09$ and $1.55 \mathrm{ppm}$ per hectare, respectively. Among major nutrients, about 100 per cent of the soil samples were low in available nitrogen, 57.60, 36.00 and 6.40 per cent soil samples were observed to be low, medium and high in available $\mathrm{P}_{2} \mathrm{O}_{5}, 87.20$ and 12.80 per cent samples were in medium and high in available K. whereas, $44.80,54.40$ and 0.80 per cent soil samples were observed to be low, medium and high in available sulphur. Nutrient indexing of the areas was low for $\mathrm{N}$ (1.00), $\mathrm{Cu}$ (1.016) and $\mathrm{Mn}$ (1.112), whereas, it was medium in case of phosphorus, potassium, sulphur, DTPA-Zn and Fe .With respect to micro-nutrients 66.40, 46.40, 99.2, 94.40 per cent samples were found to be deficient in DTPA-Zn, Fe, Cu and Mn, respectively. The correlation studies among the chemical characteristics showed that organic carbon contributed most towards nutrient availability and found to be positively correlated with all parameters except $\mathrm{pH}$ and $\mathrm{Zn}$.

Key words : Soil fertility, Soil nutrient index, $\mathrm{Zn}, \mathrm{Fe}, \mathrm{Mn}, \mathrm{Cu}$

How to cite this article : Kumar, Dinesh, Yadav, S.R., Kaur, Ramandeep, Choudhary, Anirudh and Meena, Brij Singh (2017). Soil fertility status and nutrient recommendations based on soil analysis of Jaisalmer district of western Rajasthan. Asian J. Soil Sci., 12 (1) : 103-107 : DOI : 10.15740/HAS/AJSS/ 12.1/103-107. 